\title{
Data report: late Pliocene to early Quaternary calcareous nannofossils, IODP Expedition 323 Site U1341, Bering Sea ${ }^{1}$
}

\author{
Elena Colmenero-Hidalgo ${ }^{2}$ and José-Abel Flores ${ }^{3}$
}

\section{Chapter contents}

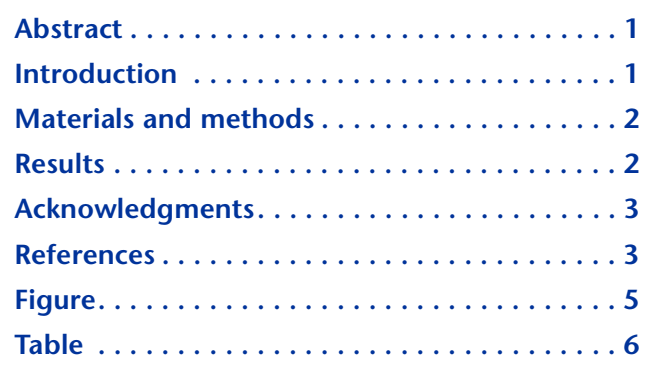

${ }^{1}$ Colmenero-Hidalgo, E., and Flores, J.-A., 2013. Data report: late Pliocene to early Quaternary calcareous nannofossils, IODP Expedition 323 Site U1341, Bering Sea. In Takahashi, K., Ravelo, A.C., Alvarez Zarikian, C.A., and the Expedition 323 Scientists, Proc. IODP, 323: Tokyo (Integrated Ocean Drilling Program Management International, Inc.). doi:10.2204/iodp.proc.323.201.2013 2Departamento de Geografía y Geología, Universidad de León, 24071 León, Spain. e.colmenero@unileon.es

${ }^{3}$ Departamento de Geología, Universidad de Salamanca, 37008 Salamanca, Spain.

\section{Abstract}

We performed semiquantitative analyses of late Pliocene-early Quaternary calcareous nannofossil assemblages in samples from Hole U1341B, recovered on the Bowers submarine ridge during Integrated Ocean Drilling Program Expedition 323 to the Bering Sea (July-September 2009). The record is characterized by very low abundances and frequent barren intervals, which have hampered our attempts of locating standard and high-latitude calcareous nannofossil biostratigraphic events. However, we have narrowed a horizon in which noted changes in the assemblage composition can be correlated to other records in the North Pacific.

\section{Introduction}

During Integrated Ocean Drilling Program (IODP) Expedition 323, a long sediment record was recovered from Site U1341 on the Bowers Ridge (Fig. F1). This location, situated in a south-central position in the Bering Sea, is presently under the influence of North Pacific surface waters entering the Bering Sea through channels between the Aleutian Islands and was proximal to the entry of the glacial Alaskan Stream (Stabeno et al., 1999; Takahashi, 2005). It is therefore a key position to link calcareous nannofossil records from the Central and North Pacific with recently available records recovered during Expedition 323.

Coccolithophores and calcareous nannofossils are widely distributed in the world's oceans since the Mesozoic and are a useful tool for paleoenvironmental analyses and age determination. In the Bering Sea, calcareous nannofossils were studied by Bukry (1973) and Worsley (1973) on materials recovered during Deep Sea Drilling Project (DSDP) Leg 19 in 1971, followed by studies by Beaufort and Ólafsson (1995), Ólafsson and Beaufort (1995), and Sato et al. (2002) on records from DSDP Leg 145 just south of the Aleutian Islands. More recently, coccolithophores have been studied on sediment traps recovered in the area (Takahashi et al., 2012). All these studies have shown that assemblages preserved in sediment records of the area are characterized by low diversities and very low numbers. Moreover, information on calcareous nannofossil assemblages in sediments older than the last glacial cycle in the Bering Sea is scarce and discontinuous because drilling procedures during DSDP Leg 19 prevented the recovery of continu- 
ous sediment records (Creager, Scholl, et al., 1973).

In this study, we analyzed the calcareous nannofossil record from Site U1341 preserved in the sediments corresponding to the late Pliocene-early Pleistocene transition $(\sim 3.5-2 \mathrm{Ma})$. Our goal was to observe the responses of different calcareous nannofossil taxa to the onset of Northern Hemisphere glaciations and correlate this record to others in the North Pacific to perform a paleoenvironmental study in this oceanic area and extend calcareous nannofossil biostratigraphic schemes to higher latitudes in the North Pacific. Regarding this last objective, the application of standard zonation schemes such as Martini (1971) to Bering Sea materials is problematic because the known biogeographical distribution of marker taxa such as discoasterids does not cover high latitudes in the Pacific Ocean (Sato et al., 2002); therefore, in the selected time interval we focused on locating the high-latitude dominance reversal noted by Sato and Kameo (1996) and Sato et al. (2002) between Dictyococcites spp. (small) and Coccolithus pelagicus, which was dated by Sato et al. (2002) to $\sim 2.75 \mathrm{Ma}$ and is considered roughly synchronous to the closure of the Isthmus of Panama and the onset of Northern Hemisphere glaciation.

\section{Materials and methods}

Site U1341 is one of three sites drilled on the Bowers Ridge during Expedition 323. Hole U1341B reached a maximum depth of 600.0 meters below seafloor (mbsf), and its bottom was preliminarily dated to $\sim 5$ Ma. Onboard results showed that calcareous nannofossils were present along the entire record, although they were a minor component of the microfossil assemblage, with frequent barren intervals below 200 mbsf (see the "Site U1341" chapter [Expedition 323 Scientists, 2011b]).

For this study, samples were selected from Cores 323U1341B-35H through 60X (Table T1). For each core, a small amount of sediment was picked with a toothpick or small spatula at a set horizon in each section and saved in a labeled plastic sample bag. Once ashore, sample bags were carefully opened and sediment was left to dry. For most samples, sediment was weighed once dried and slides were prepared for nannofossil counts following the decantation technique of Flores and Sierro (1997), which allows the calculation of numbers of calcareous nannofossils per gram. For the remaining samples, smear slides were carefully prepared following a standard smear slide preparation technique. In both cases, Canada balsam was used to seal the slides.

All samples were studied using a Zeiss polarized light microscope at $1250 \times$ magnification. A variable num- ber of fields of view (FOV; always >150) were observed in each sample.

For every sample, we estimated the total abundance of calcareous nannofossils and the abundance of each calcareous nannofossil taxon as follows:

$\mathrm{D}=$ dominant; more than half of the specimens in FOV belong to this taxon.

$\mathrm{A}=$ abundant; $>1$ specimen per FOV.

$\mathrm{C}=$ common; $\geq 1$ specimen per FOV.

$\mathrm{F}=$ few $;<1$ specimen per $2-10 \mathrm{FOV}$.

$\mathrm{R}=$ rare; $<1$ specimen per 11-100 FOV.

$\mathrm{B}=$ barren; no calcareous nannofossils present.

As to preservation, etching and overgrowth are the main features. In order to establish a ranking of preservation, we followed the code provided by Raffi and Flores (1995), who proposed four categories depending on the "average" state of preservation of the specimens examined in the smear slides:

$\mathrm{G}$ = good; little or no evidence of dissolution and/or overgrowth, and specimens are identifiable to the species level.

$\mathrm{M}-\mathrm{G}=$ moderate to good; minor to moderate dissolution and/or overgrowth, but most specimens are identifiable to the species level.

$\mathrm{M}$ = moderate; moderate dissolution and/or overgrowth, and identification to the species level is difficult.

$\mathrm{P} \quad=$ poor; extreme dissolution and/or overgrowth.

Calcareous nannofossil core catcher samples from this interval analyzed onboard for biostratigraphic purposes (see the "Site U1341" chapter [Expedition 323 Scientists, 2011b]) are also included in Table T1.

\section{Results}

\section{Abundance and preservation}

In the studied interval, the abundance of calcareous nannofossils is generally very low, with frequent barren intervals. Only Samples 323-U1341B-37H-1W, 75 $\mathrm{cm}$, and 58X-5W, $75 \mathrm{~cm}$, and core catcher Samples $36 \mathrm{H}-\mathrm{CC}, 52 \mathrm{H}-\mathrm{CC}, 54 \mathrm{H}-\mathrm{CC}, 58 \mathrm{X}-\mathrm{CC}$, and $61 \mathrm{X}-\mathrm{CC}$ yield relatively high numbers of calcareous nannofossils (Table T1).

When present, calcareous nannofossils are moderately preserved, with better preservation associated to higher numbers. Dissolution of elements is the most important preservation feature, with no overgrowth observed.

As stated above, barren intervals are distinctive in the record and can be an indication of low calcareous nannofossil production and/or carbonate preser- 
vation problems during diagenesis due to high organic matter content in sediments. More data on geochemical proxies and other calcareous microfossil groups is needed to assess this issue that affects all Bering Sea calcareous nannofossil records (see the "Expedition 323 summary" chapter [Expedition 323 Scientists, 2011a]).

\section{Calcareous nannofossil taxonomy}

As a general rule, we identified different taxa following Hine and Weaver (1998) and Young (1998). However, taxa considered in this study are mainly included within the families Noelaerhabdaceae (genera Reticulofenestra and Dictyococcites) and the genus Coccolithus (Table T1). For the former, we have adopted the criterion for the open/closed central area respectively, whereas we divided C. pelagicus into C. pelagicus and Coccolithus braarudii, in accordance with Sáez et al. (2003). In both cases, we used readily identifiable features under cross-polarized light, such as central area or coccolith size.

\section{Calcareous nannofossil stratigraphy}

Because of low abundances, barren intervals, and, more importantly, the absence of the usual marker taxa (Table T1), it has been impossible to apply any calcareous nannofossil standard zonation schemes such as Martini (1971) or Okada and Burky (1980) to the samples in this study. We have focused instead on narrowing the reversal in abundance between Dictyococcites spp. and C. pelagicus $(\sim 2.75 \mathrm{Ma}$ at nearby Ocean Drilling Program Site 883 in the North Pacific; Datum plane A in Sato et al., 2002). Variations in the calcareous nannofossil assemblages shown in Table T1 indicate that this datum lies between 388 mbsf (Sample 323-U1341B-42H-1W, 75 cm; predominantly Dictyococcites spp.) and 2346 mbsf (Sample 37H-1W, $75 \mathrm{~cm}$; predominantly C. pelagicus). Because barren horizons are particularly frequent in this interval, it is impossible to locate this event at higher resolution. However, our results are in agreement with age estimations based on other proxies (see the "Expedition 323 summary" chapter [Expedition 323 Scientists, 2011a]).

\section{Acknowledgments}

This research uses samples and data provided by the Integrated Ocean Drilling Program (IODP). We wish to express our thanks to the IODP Expedition 323 Shipboard Scientific Party and technical crew for their encouragement and assistance in sample collection onboard the $\mathrm{R} / \mathrm{V}$ JOIDES Resolution. We are thankful to J.I. Martín Cruz (University of Salamanca) for his help with sample processing and to
Dr. Filomena Ornella Amore for reviewing this manuscript. Participation during Expedition 323 and in this study was funded by Acción Complementaria CTM2009-06015-E/MAR (Spanish Government).

\section{References}

Beaufort, L., and Ólafsson, G., 1995. Data report: Upper Cretaceous and Paleogene calcareous nannofossils from the North Pacific. In Rea, D.K., Basov, I.A., Scholl, D.W., and Allan, J.F. (Eds.), Proc. ODP, Sci. Results, 145: College Station, TX (Ocean Drilling Program), 633-638. doi:10.2973/odp.proc.sr.145.103.1995

Bukry, D., 1973. Coccoliths and silicoflagellates from Deep Sea Drilling Project Leg 19, North Pacific Ocean and Bering Sea. In Creager, J.S., Scholl, D.W., et al., Init. Repts. DSDP, 19: Washington, DC (U.S. Govt. Printing Office), 857-867. doi:10.2973/dsdp.proc.19.131.1973

Creager, J.S., Scholl, D.W., et al., 1973. Init. Repts. DSDP, 19: Washington (U.S. Govt. Printing Office). doi:10.2973/ dsdp.proc.19.1973

Expedition 323 Scientists, 2011a. Expedition 323 summary. In Takahashi, K., Ravelo, A.C., Alvarez Zarikian, C.A., and the Expedition 323 Scientists, Proc. IODP, 323: Tokyo (Integrated Ocean Drilling Program Management International, Inc.). doi:10.2204/

iodp.proc.323.101.2011

Expedition 323 Scientists, 2011b. Site U1341. In Takahashi, K., Ravelo, A.C., Alvarez Zarikian, C.A., and the Expedition 323 Scientists, Proc. IODP, 323: Tokyo (Integrated Ocean Drilling Program Management International, Inc.). doi:10.2204/iodp.proc.323.105.2011

Flores, J.A., and Sierro, F.J., 1997. Revised technique for calculation of calcareous nannofossil accumulation rates. Micropaleontology 43(3):321-324. doi:10.2307/1485832

Hine, N., and Weaver, P.P.E., 1998. Quaternary. In Bown P.R. (Ed.), Calcareous Nannofossil Biostratigraphy: Dordrecht (Kluwer Academic Publishers), 266-283.

Martini, E., 1971. Standard Tertiary and Quaternary calcareous nannoplankton zonation. In Farinacci, A. (Ed.), Proc. Second Planktonic Conf. Roma 1970: Rome (Ed. Tecnosci.), 2:739-785.

Okada, H., and Bukry, D., 1980. Supplementary modification and introduction of code numbers to the low-latitude coccolith biostratigraphic zonation (Bukry, 1973; 1975). Mar. Micropaleontol., 5:321-325. doi:10.1016/ 0377-8398(80)90016-X

Ólafsson, G., and Beaufort, L., 1995. Data report: Oligocene-Pleistocene calcareous nannofossils from Leg 145. In Rea, D.K., Basov, I.A., Scholl, D.W., and Allan, J.F. (Eds.), Proc. ODP, Sci. Results, 145: College Station, TX (Ocean Drilling Program), 599-632. doi:10.2973/ odp.proc.sr.145.109.1995

Raffi, I., and Flores, J.-A., 1995. Pleistocene through Miocene calcareous nannofossils from eastern equatorial Pacific Ocean (Leg 138). In Pisias, N.G., Mayer, L.A., Janecek, T.R., Palmer-Julson, A., and van Andel, T.H. (Eds.), Proc. ODP, Sci. Results, 138: College Station, TX 
(Ocean Drilling Program), 233-286. doi:10.2973/ odp.proc.sr.138.112.1995

Sáez, A.G., Probert, I., Geisen, M., Quinn, P., Young, J.R., and Medlin, L.K., 2003. Pseudo-cryptic speciation in coccolithophores. Proc. Natl. Acad. Sci., 100(12):71637168. doi:10.1073/pnas.1132069100

Sato, T., and Kameo, K., 1996. Pliocene to Quaternary calcareous nannofossil biostratigraphy of the Arctic Ocean, with reference to late Pliocene glaciation. In Thiede, J., Myhre, A.M., Firth, J.V., Johnson, G.L., and Ruddiman, W.F. (Eds.), Proc. ODP, Sci. Results, 151: College Station, TX (Ocean Drilling Program), 39-59. doi:10.2973/ odp.proc.sr.151.112.1996

Sato, T., Saito, T., Yuguchi, S., Nakagawa, H., Kameo, K., and Takayama, T., 2002. Late Pliocene calcareous nannofossil paleobiogeography of the Pacific Ocean: evidence for glaciation at $2.75 \mathrm{Ma}$. Rev. Mex. Cienc. Geol., 19(3):175-189.

Stabeno, P.J., Schumacher, J.D., and Ohtani, K., 1999. The physical oceanography of the Bering Sea. In Loughlin, T.R., and Ohtani, K. (Eds.), Dynamics of the Bering Sea: A Summary of Physical, Chemical, and Biological Characteristics, and a Synopsis of Research on the Bering Sea: Fairbanks (Univ. Alaska Sea Grant), 1-28.
Takahashi, K., 2005. The Bering Sea and paleoceanography. Deep-Sea Res., Part II, 52(16-18):2080-2091. doi:10.1016/j.dsr2.2005.08.003

Takahashi, K., Asahi, H., Okazaki, Y., Onodera, J., Tsutsui, H., Ikenoue, T., Kanematsu, Y., Tanaka, S., and Iwasaki, S., 2012. Museum archives of the 19 years long timeseries sediment trap samples collected at central subarctic Pacific Station SA and Bering Sea Station AB during 1990-2010. Mem. Fac. Sci., Kyushu Univ., Ser. D: Earth Planet. Sci., 32(4):1-38. http://hdl.handle.net/2324/ 21002

Worsley, T.R., 1973. Calcareous nannofossils: Leg 19 of the Deep Sea Drilling Project. In Creager, J.S., Scholl, D.W., et al., Init. Repts. DSDP, 19: Washington (U.S. Govt. Printing Office), 741-750. doi:10.2973/ dsdp.proc.19.126.1973

Young, J.R., 1998. Neogene. In Bown, P.R. (Ed.), Calcareous Nannofossil Biostratigraphy: Dordrecht, The Netherlands (Kluwer Academic Publ.), 225-265.

Initial receipt: 31 July 2012

Acceptance: 10 May 2013

Publication: 21 June 2013

MS 323-201 
Figure F1. Locations of the Bowers Ridge and Site U1341 (red circle) in the Bering Sea.

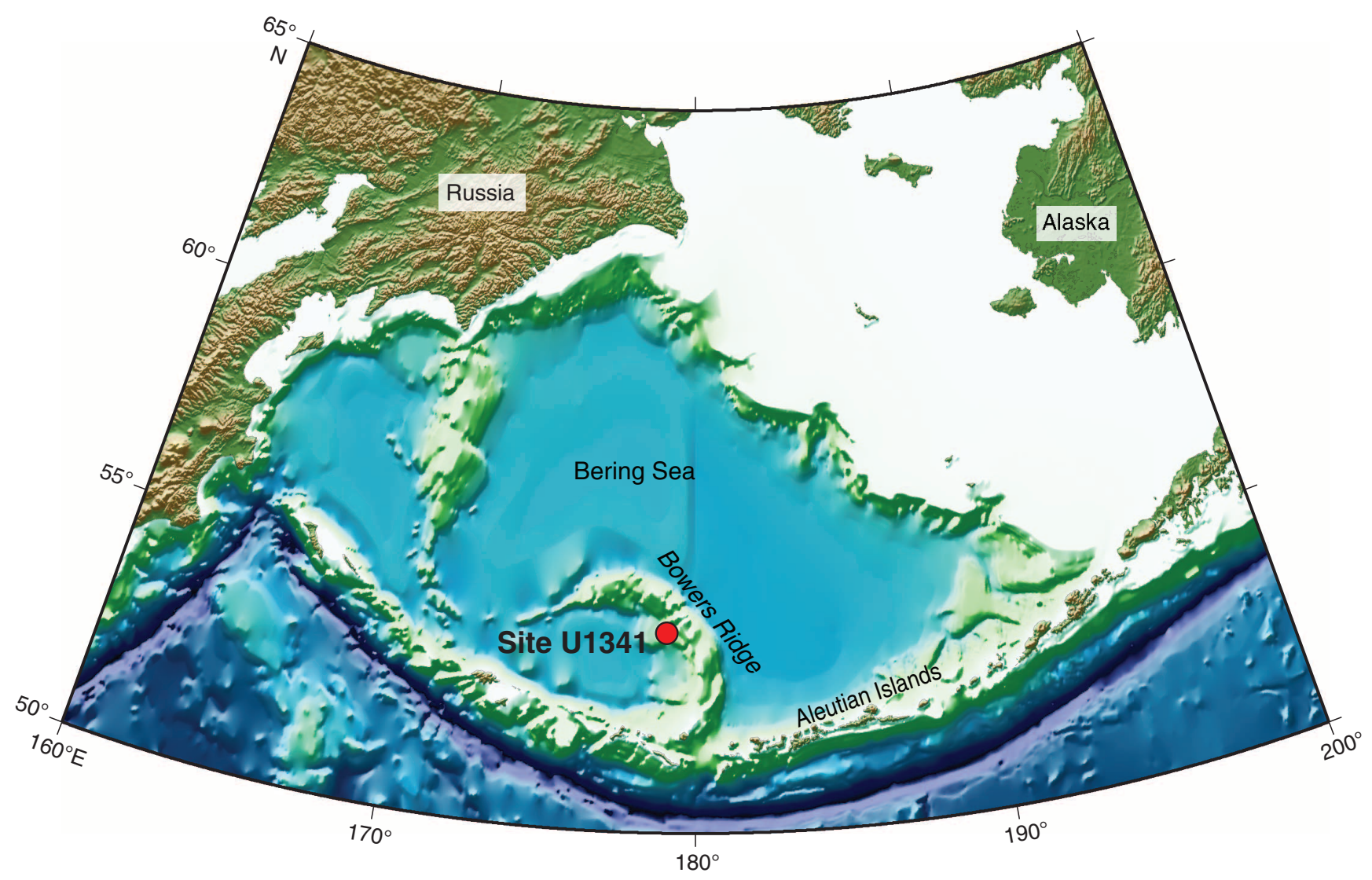


Table T1. Late Pliocene-early Quaternary calcareous nannofossil abundance, Hole U1341B. (Continued on next page.)

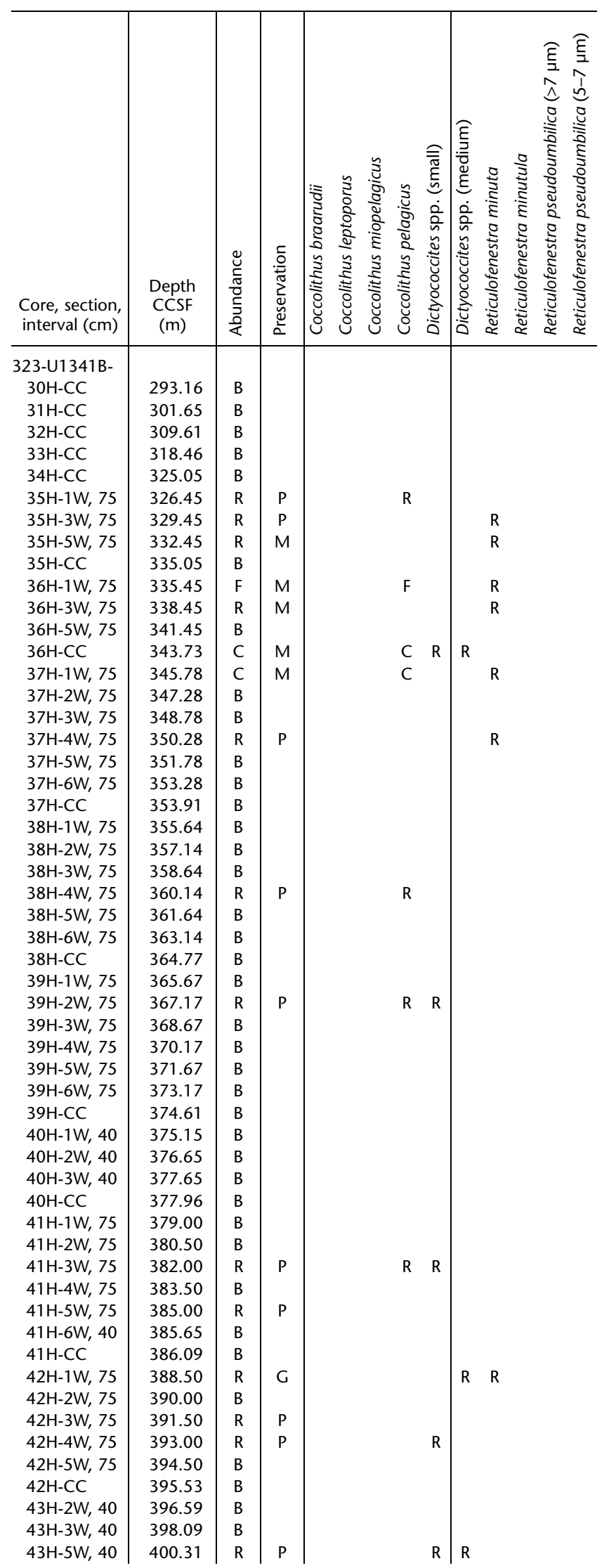


Table T1 (continued).

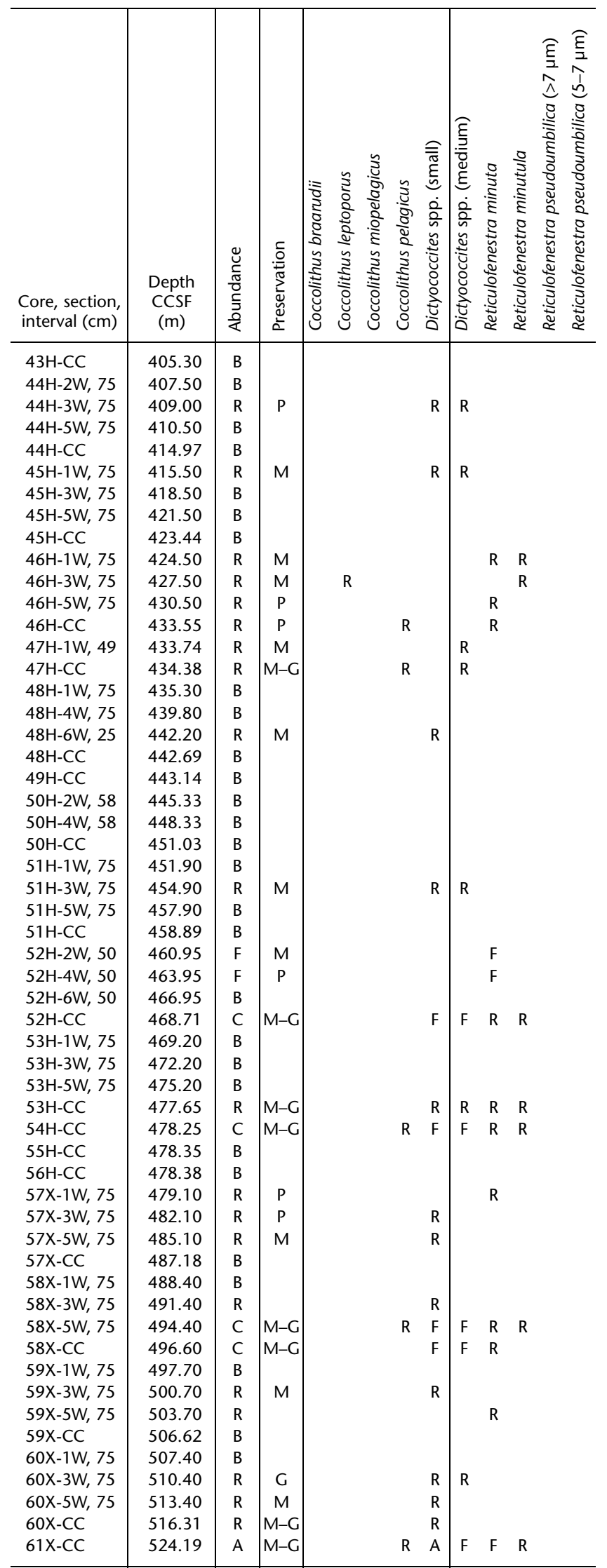

Abundance: $A=$ abundant,$C=$ common, $F=$ few, $R=$ rare, $B=$ barren. Preservation: $G=$ good, $M=$ moderate, $P=$ poor. 